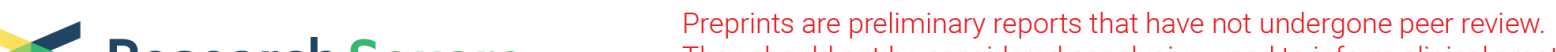

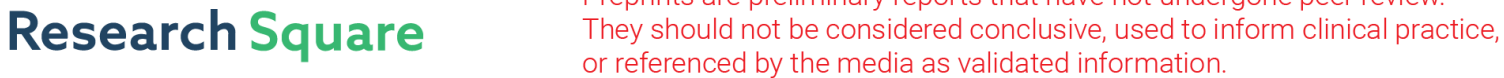

\section{Evaluation of Circulating microRNAs as Non- Invasive Biomarkers in the Diagnosis of Ovarian Cancer - A Case-Control Study}

Kai Berner ( $\nabla$ kai.berner@uniklinik-freiburg.de)

Universitatsklinikum Freiburg Klinik fur Frauenheilkunde https://orcid.org/0000-0002-7308-380X

Marc Hirschfeld

Universitatsklinikum Freiburg Klinik fur Frauenheilkunde

Daniela Weiß

Universitatsklinikum Freiburg Klinik fur Frauenheilkunde

Gerta Rücker

Albert-Ludwigs-Universitat Freiburg Institut fur Medizinische Biometrie und Medizinische Informatik

Jasmin Asberger

Universitatsklinikum Freiburg Klinik fur Frauenheilkunde

Andrea Ritter

Universitatsklinikum Freiburg Klinik fur Frauenheilkunde

Claudia Nöthling

Universitatsklinikum Freiburg Klinik fur Frauenheilkunde

Markus Jäger

Universitatsklinikum Freiburg Klinik fur Frauenheilkunde

Ingolf Juhasz-Böss

Universitatsklinikum Freiburg Klinik fur Frauenheilkunde

Thalia Erbes

Universitatsklinikum Freiburg Klinik fur Frauenheilkunde

\section{Research}

Keywords: microRNAs, ovarian cancer, liquid biopsies, urine, disease biomarker, urinary microRNAs, hypoxia, acidosis

Posted Date: May 13th, 2020

DOI: https://doi.org/10.21203/rs.3.rs-28389/v1

License: (a) (i) This work is licensed under a Creative Commons Attribution 4.0 International License.

Read Full License 
Version of Record: A version of this preprint was published at Archives of Gynecology and Obstetrics on December 10th, 2021. See the published version at https://doi.org/10.1007/s00404-021-06287-1. 


\section{Abstract}

Background Ovarian cancer is the seventh most frequent form of malignant diseases in women worldwide and over 150.000 women die from it every year. More than 70 percent of all ovarian cancer patients are diagnosed at a late stage disease with poor prognosis necessitating the development of sufficient screening biomarkers. MicroRNAs displayed promising potential as early diagnostics in various malignant diseases including ovarian cancer. The presented study aimed at identifying single microRNAs and microRNA combinations detecting ovarian cancer in vitro and in vivo.

Methods Intracellular, extracellular and urinary microRNA expression levels of twelve microRNAs (let-7a, let-7d, miR-10a, miR-15a, miR-15b, miR-19b, miR-20a, miR-21, miR-100, miR-125b, miR-155, miR-222) were quantified performing quantitative real-time-PCR. Therefore, the three ovarian cancer cell lines SK-OV-3, OAW-42, EFO-27 as well as urine samples of ovarian cancer patients and healthy controls were analyzed.

Results MiR-15a, miR-20a and miR-222 showed expression level alterations extracellularly, whereas miR$125 \mathrm{~b}$ did intracellularly across the analyzed cell lines. MicroRNA expression alterations in single cell lines suggest subtype specificity in both compartments. Hypoxia and acidosis showed scarce effects on single miRNA expression levels only. Furthermore, we were able to demonstrate the feasibility to clearly detect the 12 miRNAs in urine samples. In urine, miR-15a was upregulated whereas let-7a was down-regulated in ovarian cancer patients.

Conclusion Intracellular, extracellular and urinary micoRNA expression alterations emphasize their great potential as biomarkers in liquid biopsies. Especially miR-15a and let-7a qualify for possible circulating biomarkers in liquid biopsies of ovarian cancer patients.

\section{Background}

Ovarian cancer $(\mathrm{OC})$ is the seventh most frequent form of malignant diseases in women worldwide with an incidence of nearly 300,000 in 2018 . Due to difficulties in detecting it at an early stage, over 150,000 women die from it every year, placing it as the most lethal malignant gynecologic disease in terms of mortality $(10,19)$. Over 70 percent of OC patients are diagnosed at an advanced, incurable stage (stages III and IV) with a five-year survival rate of $29 \%$ and only $15 \%$ are diagnosed when the disease is still localized $(30,61)$. Established diagnostic tools such as TVS or CA-125 biomarker have had limited success in the early detection of OC (sensitivity in stage $\mathrm{I} / \mathrm{IIOC}<60 \%$ and overall $<88.6 \%)(6,20,39)$ as well as protein-based biomarkers like lysophosphatide acid, and the human epididymis protein 4 and multimodality screenings including the OVA1-Test and the OvaSure-Test $(32,33,45,46,49,70)$.

Where the latter diagnostic methods could not provide satisfying results, miRNAs have shown promising potential as biomarkers in various malignant diseases such as breast cancer (BC) (2). Urinary miRNAs, in particular, have shown great potential in BC (18), but also in bladder, urothelial, prostate, kidney, liver and pancreatic cancer $(15,22,76)$. MiRNAs are small, single-stranded and non-coding RNA-molecules counting approximately $20-22$ nucleotides $(3,70)$ and could be detected in body fluids of healthy and 
diseased patients. Incorporated into the RNA-induced silencing complex (RISC), miRNAs play a key role in specifically regulating messenger RNAs (mRNAs) posttranscriptionally $(13,16,17)$. They are involved in apoptosis, carcinogenesis, metastasis, invasion, proliferation and chemoresistance in general and in OC specifically $(50,55,67,70)$ and play an important role as oncogenes and tumor suppressor genes $(1,7)$ and they are up-/downregulated during carcinogenesis since they are binding to fragile regions on several chromosomes $(22,27)$. Furthermore, multiple analyses have proven exosomal trafficking of miRNAs which confirms their role in cell-cell communication and therefore as possible circulating biomarkers (51). MiRNAs in contrast to proteins as biomarkers display different advantages: expression level alterations occur simultaneously to the underlying biological mechanisms, stability in most endogenous and exogenous fluids and under extreme conditions like high temperatures, long term storage and extreme pH-values like in urine $(51,70,72)$.

\section{OC specific microRNAs in vitro}

Zhang et al. conducted cell culture analyses investigating the expression levels of 173 different miRNAs in 18 epithelial ovarian cancer (EOC) and four immortalized human ovarian surface epithelium cell lines (79). 31 miRNAs including let-7d and miR-127 showed decreased expression levels in the malignant cell lines whereas only four miRNAs expressed higher. Interestingly, miR-15a could not be detected in $23.9 \%$ of the investigated $\mathrm{OC}$ cell lines suggesting its role as tumor suppressor. Furthermore, thirteen miRNAs and especially miR-15a, miR-34a and miR-34b exhibited a higher degree of downregulation in late stage cancers (79). In another cell culture study, the miR-200 family only was significantly altered in OC cell lines compared to normal epithelial ovarian surface cells $(p=0.05)(22,59)$.

Regarding hypoxia and acidosis, Giannakakis et al. were able to demonstrate that miR-210 was upregulated under hypoxic conditions (23). Furthermore, miR-210 evolved to be regulated by hypoxia inducible factor, strengthening its putative role in targeting genes involved in hypoxia-driven malignant cellular mechanisms (23). However, reports on hypoxia- or acidosis driven aberrations of miRNA expression levels in $\mathrm{OC}$ have been rare. Still, there are investigations reporting such aberrations in various tumor entities including endometrial, breast, colon and nasopharyngeal cancer cell lines $(5,17,41)$. Molecularly both, hypoxia and acidosis, are crucial conditions in cancer development, survival, angiogenesis, invasion and metastasis $(17,25)$.

\section{OC specific tissue microRNAs}

In their microarray-based study, Dahiya et al. found 56 deregulated miRNAs in 34 OC tissue samples and 28 deregulated miRNAs in ten OC cell lines in contrast to the miRNA expression levels of ovarian superficial epithelial cells with 14 miRNAs deregulated in both (see Table 1) (14). Among these miR-221 showed the highest upregulation whereas miR-21 showed the strongest downregulation. Regarding OC tissue only, they found 25 miRNAs upregulated including miR-100 and 31 miRNAs downregulated including miR-21 and miR-155. Regarding OC cell lines only, they found five miRNAs upregulated and 23 miRNAs downregulated including miR-21, let-7d and miR-155. They also revealed that only 16 of a total number of 192 investigated miRNAs showed consistent up- or downregulation comparing their results 
with different other miRNA studies (14). lorio et al. analyzed 69 EOC tissue samples and compared them to 15 normal epithelial ovarian samples using miRNA microarray analysis (31). MiR-200a, miR-141, miR200c and miR-200b were upregulated and miR-199a, miR-140, miR-145 and miR-125b1 were downregulated in EOC only and their results allowed to separate the three different EOC histotypes serous, endometrioid and clear cell (31). 
Table 1

Overview of all included studies on miRNA expression levels in OC

\begin{tabular}{|c|c|c|c|}
\hline Reference & Histology & $\begin{array}{l}\text { Analyzed } \\
\text { Matrix }\end{array}$ & Findings \\
\hline \multirow{5}{*}{$\begin{array}{l}\text { Zhang et al. } \\
2008\end{array}$} & EOC & \multirow[t]{5}{*}{ In vitro } & Upregulated: \\
\hline & \multirow[t]{4}{*}{ FIGO: all } & & miR-26b, miR-182, miR-103, \\
\hline & & & miR-26a \\
\hline & & & Downregulated: \\
\hline & & & $\begin{array}{l}\text { miR-127, miR-134, miR-154*, miR-410, miR-377, miR-100, } \\
\text { miR-432, miR-368, miR-154, miR-495, miR-376a, miR-323, } \\
\text { miR-376b, miR-370, miR-299, let7d, miR-155, miR-140, } \\
\text { miR-222, miR-337, miR-124a, miR-99a, miR-331, miR-104, } \\
\text { miR-150, miR-184, miR-152, miR-145, miR-424, miR-224, } \\
\text { miR-302c }\end{array}$ \\
\hline \multirow{4}{*}{$\begin{array}{l}\text { Dahiya et al. } \\
2008\end{array}$} & \multirow{4}{*}{$\begin{array}{l}\text { All } \\
\text { subtypes } \\
\text { FIGO: all }\end{array}$} & \multirow{4}{*}{$\begin{array}{l}\text { Tissue } \\
\text { In vitro }\end{array}$} & Upregulated: \\
\hline & & & miR-221, miR-146b, miR-508 \\
\hline & & & Downregulated: \\
\hline & & & $\begin{array}{l}\text { let-7f, miR-106b, miR-134, miR-155, miR-21, miR-346, } \\
\text { miR-422a, miR-424, miR-519a, miR-648, miR-662 }\end{array}$ \\
\hline \multirow{4}{*}{$\begin{array}{l}\text { lorio et al. } \\
2007\end{array}$} & EOC & Tissue & Upregulated: \\
\hline & \multirow[t]{3}{*}{ FIGO: all } & \multirow[t]{3}{*}{ In vitro } & miR-200a, miR-200b, miR-200c, miR-141 \\
\hline & & & Downregulated: \\
\hline & & & $\begin{array}{l}\text { miR-140, miR-199a, miR-199b, miR-145, miR-143, miR- } \\
\text { 125a, miR-125b, miR-101, miR-212, miR-222 }\end{array}$ \\
\hline \multirow{4}{*}{$\begin{array}{l}\text { Yang et al. } \\
2008\end{array}$} & EOC & Tissue & Upregulated: \\
\hline & \multirow[t]{3}{*}{ FIGO: all } & \multirow[t]{3}{*}{ In vitro } & $\begin{array}{l}\text { miR-199a, miR-424, miR-302d, miR-320, miR-214, miR- } \\
\text { 200a, miR-29a }\end{array}$ \\
\hline & & & Downregulated: \\
\hline & & & $\begin{array}{l}\text { miR-493, miR-494, miR-125b, miR-100, let-7a, let-7b, let- } \\
\text { 7c }\end{array}$ \\
\hline
\end{tabular}




\begin{tabular}{|c|c|c|c|}
\hline Reference & Histology & $\begin{array}{l}\text { Analyzed } \\
\text { Matrix }\end{array}$ & Findings \\
\hline \multirow{4}{*}{$\begin{array}{l}\text { Nam et al. } \\
2008\end{array}$} & SEOC & \multirow[t]{4}{*}{ Tissue } & Upregulated: \\
\hline & \multirow[t]{3}{*}{ FIGO: all } & & $\begin{array}{l}\text { miR-200b, miR-21, miR-200c, miR-141, miR-20a, miR-27a, } \\
\text { miR-16, miR-93 }\end{array}$ \\
\hline & & & Downregulated: \\
\hline & & & $\begin{array}{l}\text { miR-145, miR-125b, miR-100, miR-99a, miR-26a, miR-10b, } \\
\text { miR-143, miR-214, let-7b, miR-29a, miR-125a }\end{array}$ \\
\hline \multirow{4}{*}{$\begin{array}{l}\text { Wyman et al. } \\
2009\end{array}$} & $\begin{array}{l}\text { All } \\
\text { subtypes }\end{array}$ & \multirow[t]{4}{*}{ Tissue } & Upregulated: \\
\hline & \multirow[t]{3}{*}{$\begin{array}{l}\text { FIGO: III } \\
+ \text { IV }\end{array}$} & & $\begin{array}{l}\text { miR-182, miR-200c, miR-142-3p, miR-200b, miR-135b, } \\
\text { miR-200a, miR-195, miR-126*, miR-26b, miR-10b, miR- } \\
\text { 126, miR-199b-5p, miR-107, miR-30b, miR-192, miR-335, } \\
\text { miR-32, miR-20a, miR-30c, miR-143, miR-92a, miR-199b- } \\
\text { 3p, miR-99a, miR-26a, miR-18a, miR-16, miR-15a, miR- } \\
\text { 30e, miR-194, miR-29c, miR-30d, miR-106b, }\end{array}$ \\
\hline & & & Downregulated: \\
\hline & & & $\begin{array}{l}\text { miR-127-3p, miR-377*, miR-382, miR-493, miR-409-3p, } \\
\text { miR-193a-5p, miR-210, miR-935, miR-100, miR-31, miR- } \\
\text { 22, miR-152, miR-379, miR-185, miR-221, miR-744, miR- } \\
\text { 21* let-7a*, miR-574-5p, miR-31*, miR-130b, miR-149, } \\
\text { miR-423-5p, miR-1308, miR-629, miR-320a }\end{array}$ \\
\hline \multirow[t]{3}{*}{ Calura et al. } & EOC & Tissue & Upregulated: \\
\hline & \multirow[t]{2}{*}{ FIGO: I } & \multirow{2}{*}{$\begin{array}{l}\text { (histotype } \\
\text { specificity } \\
\text { examined) }\end{array}$} & miR-30a, miR-30a*, miR-192/194 cluster \\
\hline & & & Downregulated: none \\
\hline \multirow[t]{3}{*}{ Taylor et al. } & SEOC & Serum & Upregulated: \\
\hline & \multirow[t]{2}{*}{ FIGO: all } & & $\begin{array}{l}\text { miR-21, miR-141, miR-200a, miR-200b, miR-200c, miR- } \\
\text { 203, miR-205, miR-214 }\end{array}$ \\
\hline & & & Downregulated: none \\
\hline \multirow[t]{3}{*}{ Chung et al. } & SEOC & Serum & Upregulated: none \\
\hline & \multirow[t]{2}{*}{ FIGO: all } & & Downregulated: \\
\hline & & & miR-132, miR-26a, let7-b, miR-145 \\
\hline \multirow{3}{*}{$\begin{array}{l}\text { Surayawanshi } \\
\text { et al. }\end{array}$} & \multirow{2}{*}{$\begin{array}{l}\text { SEOC+ } \\
\text { others }\end{array}$} & \multirow[t]{3}{*}{ Plasma } & Upregulated: \\
\hline & & & miR-16, miR-21, miR-191, miR-16, miR-191, miR-4284 \\
\hline & FIGO: all & & Downregulated: none \\
\hline
\end{tabular}

EOC: Epithelial ovarian cancer, SEOC: serous epithelial ovarian cancer, FIGO: Fédération Internationale de Gynécologie et d'Obstétrique 


\begin{tabular}{|c|c|c|c|}
\hline Reference & Histology & $\begin{array}{l}\text { Analyzed } \\
\text { Matrix }\end{array}$ & Findings \\
\hline Resnick et al. & $\begin{array}{l}\text { SEOC + } \\
\text { others } \\
\text { FIGO: all }\end{array}$ & Serum & $\begin{array}{l}\text { Upregulated: } \\
\text { miR-21, miR92, miR-93, miR-126, miR-29a } \\
\text { Downregulated: } \\
\text { miR-155, miR-127, miR-99b }\end{array}$ \\
\hline Häusler et al. & $\begin{array}{l}\text { SEOC+ } \\
\text { others } \\
\text { Recurrent } \\
\text { disease }\end{array}$ & $\begin{array}{l}\text { Whole } \\
\text { blood }\end{array}$ & $\begin{array}{l}\text { Upregulated: miR-30c-1 } \\
\text { Downregulated: } \\
\text { miR-342-3p, miR-181a, miR-450-5p }\end{array}$ \\
\hline Zheng et al. & $\begin{array}{l}\text { All } \\
\text { subtypes } \\
\text { FIGO: all }\end{array}$ & Plasma & $\begin{array}{l}\text { Upregulated: } \\
\text { miR-205 } \\
\text { Downregulated: } \\
\text { let-7f }\end{array}$ \\
\hline Meng et al. & $\begin{array}{l}\text { SEOC + } \\
\text { others } \\
\text { FIGO: all }\end{array}$ & Serum & $\begin{array}{l}\text { Upregulated: } \\
\text { miR-7, miR-429 } \\
\text { Downregulated: } \\
\text { miR-25, miR-93 }\end{array}$ \\
\hline $\begin{array}{l}\text { Kapetanakis } \\
\text { et al. }\end{array}$ & $\begin{array}{l}\text { All } \\
\text { subtypes } \\
\text { FIGO: all }\end{array}$ & & $\begin{array}{l}\text { Upregulated: } \\
\text { miR-200b } \\
\text { Downregulated: none }\end{array}$ \\
\hline Kan et al. & $\begin{array}{l}\text { SEOC } \\
\text { FIGO: III } \\
+ \text { IV }\end{array}$ & Serum & $\begin{array}{l}\text { Upregulated: } \\
\text { miR-182, miR-200a, miR-200b, miR-200c } \\
\text { Downregulated: none }\end{array}$ \\
\hline Shapira et al. & $\begin{array}{l}\text { SEOC } \\
\text { FIGO: all }\end{array}$ & Plasma & $\begin{array}{l}\text { Upregulated: } \\
\text { miR-1274a, miR-625-3p, miR-720 Downregulated: } \\
\text { miR-106b, miR-126, miR-150, miR-17, miR-20a, miR-92a }\end{array}$ \\
\hline
\end{tabular}




\begin{tabular}{|c|c|c|c|}
\hline Reference & Histology & $\begin{array}{l}\text { Analyzed } \\
\text { Matrix }\end{array}$ & Findings \\
\hline Zuberi et al. & $\begin{array}{l}\text { SEOC } \\
\text { FIGO: all }\end{array}$ & Serum & $\begin{array}{l}\text { Upregulated: } \\
\text { miR-200a, miR-200b, miR-200c } \\
\text { Downregulated: none }\end{array}$ \\
\hline Gao et al. & $\begin{array}{l}\text { All } \\
\text { subtypes } \\
\text { FIGO: all }\end{array}$ & Serum & $\begin{array}{l}\text { Upregulated: } \\
\text { miR-141, miR-200c } \\
\text { Downregulated: none }\end{array}$ \\
\hline Liang et al. & $\begin{array}{l}\text { All } \\
\text { subtypes } \\
\text { FIGO: all }\end{array}$ & Serum & $\begin{array}{l}\text { Upregulated: none } \\
\text { Downregulated: } \\
\text { miR-145 }\end{array}$ \\
\hline Hong et al. & $\begin{array}{l}\text { SEOC + } \\
\text { others } \\
\text { FIGO: all }\end{array}$ & Serum & $\begin{array}{l}\text { Upregulated: miR-221 } \\
\text { Downregulated: none }\end{array}$ \\
\hline Zhou et al. & $\begin{array}{l}\text { SEOC } \\
\text { FIGO: all }\end{array}$ & Urine & $\begin{array}{l}\text { Upregulated: miR-30-5p } \\
\text { Downregulated: } 37 \text { different miRNAs }\end{array}$ \\
\hline Zavesky et al. & $\begin{array}{l}\text { All } \\
\text { subtypes } \\
\text { FIGO: all }\end{array}$ & Urine & $\begin{array}{l}\text { Upregulated: } \\
\text { miR-92a, miR-200b } \\
\text { Downregulated: } \\
\text { miR-106b, miR-100 }\end{array}$ \\
\hline
\end{tabular}

Yang et al. demonstrated in a comparable setting that 36 of 515 analyzed miRNAs were deregulated in EOC compared to immortalized ovarian superficial epithelial cells (77). Among those, miR-199* as well as miR-214 and miR-200a were upregulated. MiR-100 in contrast was downregulated (77). Another study on OC tissue samples investigated the expression levels of 314 miRNAs (miRNA microarray based) in 20 serous EOCs compared to eight normal ovarian tissue samples and found that eleven miRNAs were upregulated and twelve miRNAs were downregulated (see Table 1) (52). Wyman et al. also found 123 altered miRNAs comparing stage III/IV EOC tissue samples to HCs in their study applying next generation sequencing and qRT-PCR (73). Interestingly, they also analyzed subtype specificity of serous, endometrioid and clear-cell OC and showed that 37 miRNAs were up-regulated across all subtypes including miR-15a and miR-20a and that 21 miRNAs were down-regulated across all subtypes including miR-21 and miR-100. The rest evolved to be subtype specific (73). Another study on 257 stage I EOC snap 
frozen tumor samples also showed histotype specific miRNA expression patterns although in this study a normalization against healthy tissue is missing (8). An overview of all included miRNA Studies on OC is provided in Table 1.

\section{OC specific circulating microRNAs}

New approaches target the investigation of disease specific miRNA expression profiles in human body fluids such as blood and urine aiming at an early diagnosis. The comparison of tissue and serum miRNA expression levels for example revealed a definite relationship between tissue miRNAs and tumor-derived miRNAs in human body fluids (64). Mir-132, miR-26a, let-7b and mir-145 showed promising potential as novel biomarkers in serous EOC, since they exhibited to be down-regulated in serum specimens (12). Surayawanshi et al. also compared tissue and plasma miRNA expression profiles using global profiling. They concluded that different expression profiles in both media might account for another origin of plasma miRNAs than the ovarian malignancy (63).

Resnick et al. applied qRT-PCR to compare miRNA expression profiles of 21 miRNAs in 28 EOC patients and $19 \mathrm{HCs}$ (56). Five miRNAs were upregulated and three miRNAs were downregulated in the serum of EOC patients (see Table 1) (56). Another study on whole blood OC samples of 24 OC patients with recurrent disease revealed the deregulation of 147 miRNAs in OC patients compared to HCs, with miR$30 \mathrm{c} 1$ upregulated and miR-342-3p, miR-181a and miR-450b-5p downregulated (26). Further blood- based studies on miRNA expression profiles in OC comprise the studies by Zheng et al., Meng et. al., Kapetanakis et al., Kan et al. and Shapira et al.. For detailed information see Table 1.

The miRNA-200-family underwent extensive research as diagnostic biomarker in OC. MiR-200a, miR-200b, miR-200c and miR-141 were found upregulated in the serum of OC patients in two independent studies and showed significant correlation with prognosis, tumor stage and histology $(21,82)$. MiR-145 as well as miR-221 showed promising potential in the serum-based discrimination OC patients from HCs $(28,42)$.

Zhou et al. investigated exosomal miRNA expression in urine samples of 39 serous EOC patients pre- and postsurgically, 26 patients presenting with another gynecological disease and $30 \mathrm{HCs}$ applying qRT-PCR (81). First, they found miR-30a-5p upregulated as well as 37 miRNAs downregulated comparing presurgical $\mathrm{OC}$ and $\mathrm{HC}$ samples. Second, stratifying for stage and metastatic status, they showed a distinct association between miR-30a-5p and early stage $\mathrm{OC}$ as well as lymph node metastasis. Third, in urine samples of gastric and colon cancer patients miR-30a-5p showed to be downregulated, supporting its OC specificity. And finally, in postsurgical OC samples of the same patients, the expression levels of miR-30a-5p was clearly lower than presurgically suggesting OC strongly as its origin (81). Interestingly, miR-30a-5p was upregulated in the supernatant of OC cell lines, which displays a possible excretion mechanism. As a last step, they also performed a knockout of miR-30a-5p resulting in a significant decrease of $\mathrm{OC}$ cell proliferation as well as migration (81).

Zavesky et al. analyzed cell free urine of eleven OC (also three fallopian tube cancer samples included) as well as endometrial cancer patients (78). They compared not only pre-and postsurgical specimen of the 
same patients, but also contrasted them to three HCs. Among the 18 included miRNAs, miR-92a, miR200b, miR-106b and miR-100 exhibited a significant deregulation comparing OC and HC. Mir-92a and mir200b were upregulated, while miR-100 and miR-106b were downregulated (78).

\section{Methods}

\section{Cohorts and sampling}

After the positive ethical vote (Number 36/12 and 386/16 approved by the institutional ethical review board of the University of Freiburg) as well as positive informed consent each patient included into the study provided an indefinite volume of urine. In the presented case-control-study, thirteen patients and 17 $\mathrm{HCs}$ are included for comparative analysis. The urine samples were collected at the Department of Gynecology and Obstetrics of the University Medical Center Freiburg between January 2015 and May 2016 and of the University Clinic of Bergen (Norway). Inclusion criterion for the disease group was newly diagnosed primary OC (FIGO I-IV), whereas for the control group a detailed gynecological examination without evidence of any gynecologic malignancy prior to probes collection was necessary. Exclusion criteria were previous cancer diseases, simultaneous malignancies, chemotherapy or radio-chemotherapy prior to sample collection, autoimmune diseases, diabetes mellitus type 1 and infections. OC and HC specimen were collected simultaneously and age-matched (see table 2).

All urine samples were collected in $100 \mathrm{ml}$ sterile lockable urine collection cups (Sarstedt, Germany). After the urine acquisition, all samples were stored at $-80^{\circ} \mathrm{C}$ until further processing. Prior to the final analysis, extensive centrifugation at $4.000 \mathrm{rpm}$ for five minutes was performed. 
Table 2

Ovarian cancer patients included into the study

\begin{tabular}{|c|c|c|c|c|c|c|}
\hline $\begin{array}{l}\text { Sample } \\
\text { No. }\end{array}$ & Age & Histologic subtype & Stage & TNM & Grading & $\begin{array}{l}\text { confounding } \\
\text { diagnosis }\end{array}$ \\
\hline 1 & 47 & $\begin{array}{l}\text { Serous } \\
\text { Adenocarcinoma }\end{array}$ & $\begin{array}{l}\text { FIGO } \\
\text { Illc }\end{array}$ & $\begin{array}{l}\text { pT3c, pN1, } \\
\text { cM0 }\end{array}$ & G3 & none \\
\hline 2 & 53 & $\begin{array}{l}\text { Serous } \\
\text { Adenocarcinoma }\end{array}$ & $\begin{array}{l}\text { FIGO } \\
\text { Illc }\end{array}$ & $\begin{array}{l}\text { pT2a, pN1, } \\
\text { cM0 }\end{array}$ & G3 & zoeliakie \\
\hline 3 & 56 & $\begin{array}{l}\text { Serous } \\
\text { Adenocarcinoma }\end{array}$ & $\begin{array}{l}\text { FIGO } \\
\text { Illc }\end{array}$ & $\begin{array}{l}\text { pT3c, pN1, } \\
\text { cM0 }\end{array}$ & G3 & none \\
\hline 4 & 76 & $\begin{array}{l}\text { Serous } \\
\text { Adenocarcinoma }\end{array}$ & $\begin{array}{l}\text { FIGO } \\
\text { IV }\end{array}$ & $\begin{array}{l}\text { pT3c, pN1, } \\
\text { cM0 }\end{array}$ & G3 & gastritis \\
\hline 5 & 48 & $\begin{array}{l}\text { Serous } \\
\text { Adenocarcinoma }\end{array}$ & $\begin{array}{l}\text { FIGO } \\
\text { Illc }\end{array}$ & $\begin{array}{l}\text { pT3a, pN1, } \\
\text { cM0 }\end{array}$ & G3 & hypothyreosis \\
\hline 6 & 79 & $\begin{array}{l}\text { Serous } \\
\text { Adenocarcinoma }\end{array}$ & $\begin{array}{l}\text { FIGO } \\
\text { IV }\end{array}$ & $\begin{array}{l}\text { pT3c, pN1, } \\
\text { cM0 }\end{array}$ & G3 & none \\
\hline 7 & 65 & $\begin{array}{l}\text { Serous } \\
\text { Adenocarcinoma }\end{array}$ & $\begin{array}{l}\text { FIGO } \\
\text { Illc }\end{array}$ & $\begin{array}{l}\text { pT3c, pN1, } \\
\text { cM0 }\end{array}$ & G2 & $\begin{array}{l}\text { esophagitis, bulbitis, } \\
\text { gastritis }\end{array}$ \\
\hline 8 & 24 & $\begin{array}{l}\text { Sertoli-Leydig-Cell } \\
\text { Tumor }\end{array}$ & $\begin{array}{l}\text { FIGO } \\
\text { la }\end{array}$ & $\begin{array}{l}\text { pT1a, pNo, } \\
\text { cM0 }\end{array}$ & - & none \\
\hline 9 & 63 & $\begin{array}{l}\text { Serous } \\
\text { Adenocarcinoma }\end{array}$ & $\begin{array}{l}\text { FIGO } \\
\text { lla2 }\end{array}$ & $\begin{array}{l}\text { pT3a, pN1, } \\
\text { cM1 }\end{array}$ & G3 & none \\
\hline 10 & 71 & $\begin{array}{l}\text { Serous } \\
\text { Adenocarcinoma }\end{array}$ & $\begin{array}{l}\text { FIGO } \\
\text { Illc }\end{array}$ & $\begin{array}{l}\text { pT3c, pN1, } \\
\text { cM0 }\end{array}$ & G3 & none \\
\hline 11 & - & $\begin{array}{l}\text { Serous } \\
\text { Adenocarcinoma }\end{array}$ & - & - & - & - \\
\hline 12 & - & $\begin{array}{l}\text { Serous } \\
\text { Adenocarcinoma }\end{array}$ & - & - & - & - \\
\hline 13 & - & $\begin{array}{l}\text { Serous } \\
\text { Adenocarcinoma }\end{array}$ & - & - & - & - \\
\hline
\end{tabular}

TNM: Tumorstatus identified by pathologist G: Grading FIGO: Tumorstatus according to the French organization Fédération Internationale de Gynécologie et d'Obstétrique (FIGO)

\section{Cell culture}

The established human tumor cellines, SK-OV-3 and EFO-27 and OAW-42 were cultured in a humidified incubator $\left(37^{\circ} \mathrm{C}, 5 \% \mathrm{CO}_{2}, 95 \%\right.$ air) and maintained according to the recommended cell line specific culturing conditions. Cells were transferred into $25 \mathrm{~cm}^{2}$ cell culture flasks (Greiner Bio-One, Frickenhausen, Germany) until they reached $70 \%$ confluency. For hypoxia experiments, cells were placed 
in a hypoxic chamber $\left(3 \% \mathrm{O}_{2}\right.$; mentioned as hypoxia). For acidosis experiments, culture media were supplemented with 2-Hydroxypropionic acid (Carl Roth, Karsruhe, Germany $0.2 \%$, pH 6.2). Cells were cultured in parallel experiments under normal conditions (used as control). All treatments lasted for 24 hours. Triplicates were generated. Afterwards, cells and cell culture media were processed separately. Cells underwent direct lysis according to the RNA-Isolation protocol whereas cell culture media underwent extensive centrifugation (4000 rpm for ten minutes) before further processing.

\section{RNA-Isolation, Reverse transcription, Poly-A-tailing and pre-amplification}

Two RNA isolation protocols were used: Analytic Jena's innuPREP Micro RNA Kit (Analytic Jena, Jena, Germany) for the cells and Exiqon's miRCURY RNA Isolation Kit - Biofluids (Exiqon, Qiagen GmbH, Hilden, Germany) for the liquid specimen. Before performing Exiqon's miRCURY RNA Isolation Kit - Biofluids, extensive centrifugation steps eradicated all cellular material and separated DNA from RNA. The

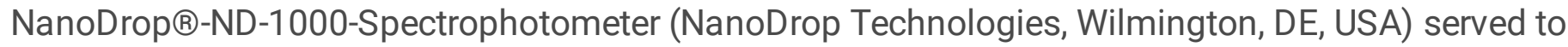
determine the RNA concentration spectrometrically. The isolated RNA was finally stored at $-20^{\circ} \mathrm{C}$ until further processing.

Subsequently, a Reverse transcription (RT) protocol was performed (miScript Reverse Transcription Kit, Qiagen $\mathrm{GmbH}$, Hilden, Germany) that generated cDNA of miRNAs only.

\section{Quantitative realtime-PCR}

Quantitative real-time polymerase chain reaction (qPCR) served as detection method for determining miRNA expression levels in cell culture, cell culture media and urine samples. We processed qPCR on the Eppendorf 480 Mastercycler (Eppendorf, Hamburg, Germany). Duplicates of each sample were analyzed. For the qPCR, one $\mu \mathrm{l}$ cDNA and nine $\mu \mathrm{l}$ of an in-house qPCR mastermix (containing TRIS pH 8.1, dATP, dCTP, dGTP, dTTP, magnesium, potassium ammonium, SYBRGreen (Jena Bioscience, Jena, Germany), enhancers, HotStart Taq Polymerase (Jena Bioscience)) were used. A negative control (ten $\mu$ mastermix, no cDNA) and a RT (no RNA for reverse transcription, $1 \mu$ unspecific cDNA, $9 \mu$ mastermix) were added, in order to evaluate if specific or unspecific products were amplified. For primer sequences see Table 3. 
Table 3

List of Primers used for qPCR

\begin{tabular}{|c|c|}
\hline Universal Antisense & 5'-GAA CAG TAT GTG TCA CAG ACG TAC-3' \\
\hline Let-7a & 5'-GCGG TGAGGTAGTAGGTTGTAT-3' \\
\hline Let-7d & 5'-GCGG AGAGGTAGTAGGTTGCATA-3' \\
\hline miR-10a & 5'-GCATG TAC CCT GTA GAT CCG A-3' \\
\hline miR-15a & 5'-GCGG TAGCAGCACATAATGGTT-3' \\
\hline miR-15b & 5'-CATG CAT AGC AGC ACA TCA TG -3' \\
\hline miR-19b & 5'-CATG TGT GCA AAT CCA TGC A -3' \\
\hline miR-20a & 5'-GCGG TAAAGTGCTTATAGTGCAG-3' \\
\hline miR-21 & 5'-GCATGCA TAG CTT ATC AGA CTG - 3' \\
\hline miR-25 & $5^{\prime}$-TCA TTG CAC TTG TCT CGG T -3' \\
\hline miR-100 & 5'-GCATT AAC CCG TAG ATC CGA-3' \\
\hline miR-103 & 5'-CGG AGCAGCATTGTACAGG-3' \\
\hline miR-125b & 5'-GCAT TCC CTG AGA CCC TAA C-3' \\
\hline miR-155 & 5'-GCATGCA TTA ATG CTA ATC GTG A -3' \\
\hline miR-191 & 5'-GCGG CGG AAT CCC AAA AGC AG-3' \\
\hline miR-222 & 5'-GCATG CTCAGTAGCCAGTGTAG-3' \\
\hline
\end{tabular}

\section{Analysis and statistics}

We applied a multivariable linear regression model to the log-transformed expression values with cell line (SK-OV-3, EFO-27, OAW-42) and its two-way and three-way interactions with treatment (control, hypoxia, acidosis) and compartment (intra-/extracellularly) as independent variables. All statistical methods involve $\Delta \mathrm{C}_{\mathrm{t}}$-values normalized against the mean value of miR-25,-103 and - 191. To calculate the influence of hypoxia and acidosis $\Delta \mathrm{C}_{\mathrm{t}}$-values of treated and untreated probes were compared statistically which is represented in the relative expression $\left(=2^{-\Delta C T}\right)$.

For the interpretation of the multivariable analysis, all miRNA expression levels are compared to the intercept. The intercept represents cell-line EFO-27 under control condition in the intracellular compartment. All statistical results with a p-value of 0.05 or lower were interpreted as significant.

\section{Results}


Summarizing, all analyzed miRNAs except miR-155 could be detected intra- and extracellularly. MiR-155 was detectable extracellularly only, however, to an extremely low degree $\left(\Delta \mathrm{C}_{\mathrm{t}}\right.$-values between 22.3429.20). Additionally, miR-21 did not show any statistically significant results neither on the intra- nor extracellular level under any analyzed condition in neither of the cell lines. The following paragraph pictures relevant findings only. All expression level regulations of miRNAs must be interpreted in comparison to the expression level of the same miRNA in the arbitrary reference (EFO-27, untreated, intracellularly). For a full list of results as well as the expression levels of each miRNA for the intercept and its confidence intervals, see supplemental data 1-3.

Intracellular expression level alterations

Focusing on intracellular expression levels only, miR-125b expression levels showed significant alterations in all analyzed cell lines. Expression levels were higher in SK-OV-3 (70.14; Cl: 10.71-459.31; p $<0.001$ ) and OAW-42 (95.99; Cl: 14.66-628.61; $p<0,001$ ) cells, compared to EFO-27 (see Fig. 1). Furthermore, in SK-OV-3, let-7d (0.35; Cl: 0.15-0.83; $p=0.02)$ and miR-222 (0.16; Cl: 0.05-0.53; $p=0.004)$ showed lower expression levels, miR-100 (10.29; Cl: 2.17-48.83; $\mathrm{p}=0.005)$ showed higher expression levels compared to EFO-27. Additionally, miR-10a (0.06; Cl: $0.01-0.44 ; \mathrm{p}=0.008)$ and let-7d $(0.40 ; \mathrm{Cl}$ : $0.17-0.95 ; p=0.041$ ) showed lower intracellular expression levels in OAW-42 cells (see Fig. 2).

Extracellular expression level alterations

Extracellularly, compared to the intercept, miR-15a and miR-20a showed altered expression levels in the analyzed OC cell lines whereas they were stable in the intracellular compartment. MiR-15a (SK-OV-3: 536.59; Cl: 29.26-9838.90; $p<0.001$; EFO-27: 428.64; Cl: 23.38-7859.65; $p<0.001$; OAW-42: 438.58; Cl: 23.92-8041.82; $p<0.001$ ) and miR-20a (SK-OV-3: 5.08; Cl: 1.84-14.00; $p=0.002$; EFO-27: 3.73; Cl: 1.3510.28; $p=0.013$; OAW-42: 5.74; Cl: 2.08-15.83; $p=0.001$ ) showed higher expression levels. In EFO-27 and OAW-42 miR-222 showed lower expression levels (EFO: 0.12; Cl: 0.03-0.42; $\mathrm{p}=0.002 ; \mathrm{OAW}-42$ : $0.14 ; \mathrm{Cl}$ : $0.04-0.48 ; p=0.003$ ) (see Fig. 3 and supplemental data for box plots, expression levels and confidence intervals). Additionally, there were expression level alterations in the extracellular compartment of the EFO-27 cell line compared to the reference: let $7 \mathrm{a}(0.11 ; \mathrm{Cl}: 0.03-0.40 ; p=0.001)$, let-7d $(0.18 ; \mathrm{Cl}: 0.07-$ $0.42 ; p<0.001)$, miR15b (0.48; 0.23-1.02; $p=0.060)$ and miR-125b (6.05; Cl: $0.92-39.61 ; p=0.065)$ and expressed lower, whereas miR-15a, miR-20a (see above) and miR-19b (3.15; Cl: 0.95-10.44; $p=0.065)$ expressed higher. In OAW-42 cells supernatant, let-7a (0.26; Cl: 0.07-0.97; $p=0.048)$ expressed lower compared to the intercept.

Expression level alterations under hypoxia and acidosis

Regarding hypoxia and acidosis, no significant miRNA alterations were visible after the application of the multivariable linear regression model. Still, the raw data and the boxplots revealed some promising miRs: in the intracellular compartment of SK-OV-3 cells, hypoxia led to an upregulation of miR-20a while acidosis led to an upregulation of miR-21. Inside OAW-42 cells, acidosis led to an upregulation of miR-19b (see Fig. 5). In EFO-27 cells, no alterations occurred. In the extracellular compartment of the SK-OV-3 cell 
line, hypoxia led to a downregulation of let-7d. Simultaneously, acidosis led to an even stronger downregulation of miRNAs let-7a and let-7d. In the OAW-42 cell line, neither hypoxia nor acidosis led to a significant alteration of the same miRNAs. In the extracellular compartment of the EFO-27 cell line, acidosis triggered a downregulation of miR-125b (see Fig. 4; for all changes caused by hypoxia and acidosis see supplemental data 1-3).

Urinary results

Finally, the expression level of miR-15a was higher in the urine of OC patients than in the urine of HCs ( $\mathrm{p}$ $=0.0319)$ whereas the expression level of let-7a was lower in OC patients $(p=0.0199)$. MiR-10a tended to be slightly downregulated in the urine of OC patients $(p=0.0571)$ (see Fig. 5). MiRNAs let 7d, miR 15b, miR 19b, miR 20a, miR 21, miR100, miR125b and miR 222 did not show significant expression level alterations and mir-155 wasn't detectable.

\section{Discussion}

The major source of existing discrepancies across studies lies in differing methodological approaches, a lack of suitable housekeeper miRNAs, disease and tumor heterogeneity as well as in the nature of miRNAs themselves.

The methodological approach and single steps of miRNA analysis has a significant impact on the final results $(40,51)$. For example, northern blotting, microarray-based detection, next generation sequencing and real-time RT-PCR differ in sensitivity and specificity and their random use has led to inconsistent results.

Dahiya et al. describe this issue in their study and literature research (13). MiRs-21, -155 and let-7d were downregulated in tissue and cell lines, whereas miR-100 showed to be upregulated in that microarraybased approach. In addition, they found that only 16 of 192 analyzed miRNAs showed consistent expression patterns across studies (13). The given study demonstrated a downregulation of let-7d in cell culture analyses intra- and extracellularly and found higher expression levels of miR-100 in the intracellular compartment of SK-OV-3 cells only.

Four more studies on OC tissue showed diverging results as well $(31,52,73,77)$. lorio et al. applied microarray analyses and found different miRNAs to be deregulated (31). MiR-125b1 was downregulated. MiR-100 showed lower expression levels in OC tissues compared to HCs (31). Nam et al. showed an upregulation of miR-20a and miR-21 in ovarian tumor tissue $(52,77)$. In the presented study, miR-125b showed a similar lower expression in EFO-27 intracellularly, extracellularly and tendentially under acidosis. In SK-OV-3 and OAW-42 cell lines, it showed higher expression levels intracellularly only. This is why it must be hypothesized that miR-125b is subtype specific. Moreover, miR-100 exhibited higher expression levels intracellularly in SK-OV-3 and miR-20a showed higher expression levels in the supernatant of all three analyzed cell lines in our study as well. 
Methodologically, Wyman et al. used next generation sequencing and subsequent qRT-PCR (73). They found miR-15a and miR-20a to be upregulated like proven extracellularly in the given study. However, they also showed a downregulation of miR-21 and miR-100 (73).

Regarding the impact of hypoxia and acidosis on miRNA expression levels in OC, results are scarce. We found sporadic alterations of miRNA expression levels as well (see results). Giannakakis et al. demonstrated the involvement of miR-210 in the HIF pathway (23). Compared to our study, hypoxia was methodologically induced using a lower amount of oxygen ( $1.5 \%$ vs. $3 \%$ ) and a different panel of miRNAs was analyzed (23). Another study on endometrial cancer cell lines also showed sporadic alterations only: miR-15a, miR-20a, miR-20b, miR-21 under hypoxia and let-7a, miR-22 and miR-125b under acidosis (17). These results were inconsistent with comparable studies (41).

We hypothesize that $\mathrm{OC}$ patients can be distinguished from $\mathrm{HC}$ comparing their urinary miRNA expression levels. However, urine as well as cell culture supernatant are both challenging for cancer detection because of their biochemical conditions. The feasibility of urinary miRNA-based detection of cancer has already been proven in other tumor entities like BC $(18,48,53)$. Several studies verified the stability of miRNAs under harsh conditions like extreme pH-values (51). Compared to proteins, miRNAs undergo less degradation through ribonucleases due to their packaging into exosomes and the RISC and also because of their small size $(26,70)$. However, the amount of total miRNA in urine and cell culture supernatant is small, which emphasizes that miRNA quantity and quality are crucial for the final detection $(22,48)$.

Targeting the correlation of tumor cell derived and urinary miRNAs, one study on OC tissue and serum of the same patients conducted by Taylor et al. found matching expression patterns of eight miRNAs and therefore hypothesized that miRNAs in the serum derive directly from the tumor itself (64). Nakamura et al. also suggest that miRNAs in biofluids reflect tissue miRNA expression levels accurately (51). Microarray analyses of tissue, ascites and serum of EOC patients also showed uniform alterations (12). However, in serum, additional miRNAs evolved to be regulated (12). In our study we detected differing miRNA signatures in cell culture, in cell culture supernatant and in urine.

Furthermore, OC detection based on urinary miRNAs is hindered by disease heterogeneity. $\mathrm{OC}$ is a highly individual disease that differs in histology, stage, metastatic status and molecular tumor-characteristics $(47,51)$. The studies conducted by lorio et al. and Calura et al. picture this as well $(8,31)$. Both showed histotype specific miRNA expression signatures. MiR-222 showed specific alteration in endometrioid and clear cell subtypes whereas miR-21 did in endometrioid subtypes only $(8,31)$. In our in vitro study, we were also able to detect subtype specific miRNA alterations.

Not only disease but also tumor heterogeneity complicate miRNA-based OC detection. Additionally, the tumor microenvironment consists of different cells and acellular components connected to different miRNA alterations. According to this, the same tumor might be able to exhibit a varying miRNA expression pattern at different states of its existence. This could explain the inconsistency of miRNA alterations across the published studies. 
For example, miR-15a as well as let-7d showed significant downregulation in a cell culture study conducted by Zhang et al. (79). Interestingly, the degree of downregulation rose with stage and wasn't detectable in $23.9 \%$ of the examined samples. They finally suggested these two miRNAs to be tumor suppressors (79). MiR-15a was neither down- nor upregulated in the intracellular compartment of the given study but was significantly elevated in the extracellular compartment of all three analyzed cell lines. This suggests that the intracellular downregulation or absence of miR-15a is a possible result of an upregulated trafficking into the tumor microenvironment.

Moreover, the significant downregulation of let-7d in OC cell lines could be proven intracellularly in SK-OV3 and OAW-42, extracellularly in EFO-27 and OAW-42 and under hypoxia and acidosis in SK-OV-3. Let-7d emerged its role as tumor suppressor by negatively regulating the RAS-pathway in lung cancer (34). In conjunction with tumor heterogeneity, tumor immunology revealed a crucial role in the development and formation of cancer specific miRNA patterns (54).

Resnick et al. identified miR-21 and miR-155 as possible biomarkers (56). While miR-21 was upregulated, miR-155 was downregulated (56). We observed this in our in vitro study as well, but not in the urine of OC patients. This suggests that urinary miRNAs express differently because of the activity of urine-specific enzymes and several cellular mechanisms. Some other blood-based studies emphasize this hypothesis showing aberrantly altered miRNAs compared to the given urine-based study $(26,35,36,44,60,80)$. However, it must be considered that the analyzed OC histologic subtypes and samples as well as the applied methods and the investigated miRNA panels varied tremendously across these six studies.

Finally, patient heterogeneity modifies the results of the given study to an unknown extent, given that each individual presents with many exogeneous as well as endogenous confounders. In detail, cardiovascular, rheumatologic, dermatologic, neurologic, renal and many other diseases lead to specific miRNA expression alterations $(22,53,69)$.

Zhou et al. performed qRT-PCR to determine exosomal miRNA expression levels (81). Not only OC samples but also benign ovarian tumors and gastric as well as colon carcinomas were analyzed and prove OC specificity of miR-30a-5p upregulation and the downregulation of 37 more miRNAs in OC exclusively (81).

Zavesky et al. performed qRT-PCR on cell free urine samples as well and found miR-100 to be downregulated (78). The strength of this work was prior assessment of RNA quality and quantity, while the inclusion of carcinomas of the fallopian tube into the study group of only 11 patients is questionable (78).

\section{Conclusion}

The landscape of miRNA studies in OC emphasizes their great potential for the detection of OC. With the given study we were able to demonstrate the feasibility of distinct miRNA-based discrimination of OC and $\mathrm{HC}$ in urine thanks to a specific miRNA signature. We were also able to widen the panel of miRs that 
potentially serve as diagnostic urinary biomarker in the detection of OC. However, our study also shows that urinary miRNA expression levels are massively dependent on methodological procedures. Comparing the few previous urine-based studies and the given study, there are several differences in the reported miRNA alterations in OC patients. This mirrors the great necessity of standardized miRNA extraction and detection protocols. Furthermore, to the best of our knowledge this study is the second one to demonstrate the feasibility to detect OC specific miRNAs in cell culture supernatant and the first to prove the traceability of single miRNAs from the intracellular to the extracellular compartment and finally to urine. MiR-15a was upregulated in $\mathrm{OC}$ cell culture supernatant as well as in urine of $\mathrm{OC}$ patients which strengthens its $\mathrm{OC}$ specific diagnostic potential observed in various studies before. As this study examines a small number of samples only, future studies are crucial to verify these observations.

\section{Declarations}

\section{Ethics approval and consent to participate}

The according investigation protocols (36/12 and 386/16) were approved by the institutional ethical review board of the University of Freiburg. All patients and healthy controls involved provided written informed consent.

\section{Consent for publication}

Not applicable.

\section{Availability of data and materials}

All data generated or analyzed during this study are included in this published article and its supplementary information files. Additional information is available from the corresponding author on reasonable request.

\section{Competing interests}

The authors declare that they have no competing interests in regard to this publication.

\section{Funding}

Not applicable.

\section{Authors' contributions}

TE, MJ and MH devised the project outline and experimental study concept. MJ substantially worked out technical details of analytical assays. KB, MJ, DW and AR performed practical realization of sample handling, processing and data acquisition. KB, DW and $A R$ were responsible for study-relevant patient data administration. $\mathrm{KB}, \mathrm{TE}, \mathrm{MJ}, \mathrm{MH}$ and $\mathrm{DW}$ conducted a collective literature review. GR conceptually designed and overall guided statistical data assessment. GR performed statistical testing to extract 
decisive informative value. $\mathrm{KB}, \mathrm{JA}, \mathrm{MH}, \mathrm{TE}$ and $\mathrm{GR}$ wrote the manuscript in consultation with and under critical revision of AR, DW, IJB and JA. Final data evaluation and determination of conclusive study output were performed by $\mathrm{MH}, \mathrm{KB}, \mathrm{TE}, \mathrm{GR}$ and $\mathrm{MJ}$.

\section{Acknowledgements}

The authors are particularly grateful for continuous organizational support and technical assistance given by Mrs. Claudia Nöthling.

\section{References}

1. Akao Y, Nakagawa Y, Hirata I, lio A, Itoh T, Kojima K, Nakashima R, Kitade Y, Naoe T. 'Role of antioncomirs miR-143 and - 145 in human colorectal tumors'. Cancer Gene Ther. 2010;17(6):398. DOI:10.1038/cgt.2009.88. [Online].

2. Anderson GL, McIntosh M, Wu L, Barnett M, Goodman G, Thorpe JD, Bergan L, Thornquist MD, Scholler N, Kim N, O'Briant K, Drescher C, Urban N. 'Assessing lead time of selected ovarian cancer biomarkers: A nested case-control study'. J Natl Cancer Inst. 2010;102(1):26-38.

3. Bartel DP. (2004) 'MicroRNAs: Genomics, biogenesis, mechanism, and function', Cell, vol. 116, no. 2, pp. 281-297.

4. Beach A, Zhang H-G, Ratajczak MZ, Kakar SS. 'Exosomes: An overview of biogenesis, composition and role in ovarian cancer'. Journal of ovarian research. 2014;7:14.

5. Blick C, Ramachandran A, McCormick R, Wigfield S, Cranston D, Catto J, Harris AL. 'Identification of a hypoxia-regulated miRNA signature in bladder cancer and a role for miR-145 in hypoxia-dependent apoptosis'. British journal of cancer. 2015;113(4):634-44.

6. Buys SS, Partridge E, Black A, Johnson CC, Lamerato L, Isaacs C, Reding DJ, Greenlee RT, Yokochi LA, Kessel B, Crawford ED, Church TR, Andriole GL, Weissfeld JL, Fouad MN, Chia D, O'Brien B, Ragard LR, Clapp JD, Rathmell JM, Riley TL, Hartge P, Pinsky PF, Zhu CS, Izmirlian G, Kramer BS, Miller AB, Xu J-L, Prorok PC, Gohagan JK, Berg CD. (2011) 'Effect of screening on ovarian cancer mortality: The Prostate, Lung, Colorectal and Ovarian (PLCO) Cancer Screening Randomized Controlled Trial', JAMA, vol. 305, no. 22, pp. 2295-2303.

7. Calin GA, Croce CM. 'MicroRNA-cancer connection: The beginning of a new tale'. Cancer research. 2006;66(15):7390-4.

8. Calura E, Fruscio R, Paracchini L, Bignotti E, Ravaggi A, Martini P, Sales G, Beltrame L, Clivio L, Ceppi L, Di Marino M, Nerini F, Zanotti I, Cavalieri L, Cattoretti D, Perego G, Milani P, Katsaros R, Tognon D, Sartori G, Pecorelli E, Mangioni S, D'Incalci C, Romualdi M, C. and Marchini S. 'MiRNA landscape in stage I epithelial ovarian cancer defines the histotype specificities'. Clinical cancer research: an official journal of the American Association for Cancer Research. 2013;19(15):4114-23.

9. 'Cancer Facts \& Figs. 2018 - Special Section: Ovarian Cancer' [Online]. Available at https:// www.cancer.org/content/dam/cancer-org/research/cancer-facts-and-statistics/annual-cancer-facts- 
and-figures/2018/cancer-facts-and-figures-special-section-ovarian-cancer-2018.pdf (Accessed 26 March 2019).

10. Chen R, Alvero AB, Silasi DA, Kelly MG, Fest S, Visintin I, Leiser A, Schwartz PE, Rutherford T, Mor G. (2008) 'Regulation of IKKbeta by miR-199a affects NF-kappaB activity in ovarian cancer cells', Oncogene, vol. 27, no. 34, pp. 4712-4723.

11. Chung Y-W, Bae H-S, Song J-Y, Lee JK, Lee NW, Kim T, Lee K-w. 'Detection of microRNA as novel biomarkers of epithelial ovarian cancer from the serum of ovarian cancer patients'. International journal of gynecological cancer: official journal of the International Gynecological Cancer Society. 2013;23(4):673-9.

12. Dahiya N, Morin PJ. 'MicroRNAs in ovarian carcinomas'. Endocrine-related Cancer. 2010;17(1):F7789.

13. Dahiya N, Sherman-Baust CA, Wang T-L, Davidson B, Shih I-M, Zhang Y, Wood W, Becker KG, Morin PJ. 'MicroRNA expression and identification of putative miRNA targets in ovarian cancer'. PloS one. 2008;3(6):e2436.

14. Debernardi S, Massat NJ, Radon TP, Sangaralingam A, Banissi A, Ennis DP, Dowe T, Chelala C, Pereira SP, Kocher HM, Young BD, Bond-Smith G, Hutchins R, Crnogorac-Jurcevic T. 'Noninvasive urinary miRNA biomarkers for early detection of pancreatic adenocarcinoma'. American journal of cancer research. 2015;5(11):3455-66.

15. Di Leva G, Garofalo M, Croce CM. 'MicroRNAs in cancer'. Annual review of pathology. 2014;9:287314.

16. Eismann J, Hirschfeld M, Erbes T, Rücker G, Jäger M, Ritter A, Weiss D, Gitsch G, Mayer S. 'Hypoxiaand acidosis-driven aberrations of secreted microRNAs in endometrial cancer in vitro'. Oncol Rep. 2017;38(2):993-1004.

17. Erbes T, Hirschfeld M, Rücker G, Jaeger M, Boas J, Iborra S, Mayer S, Gitsch G, Stickeler E. 'Feasibility of urinary microRNA detection in breast cancer patients and its potential as an innovative noninvasive biomarker'. BMC Cancer. 2015;15:193.

18. Ferlay J, Soerjomataram I, Dikshit R, Eser S, Mathers C, Rebelo M, Parkin DM, Forman D, Bray F. 'Cancer incidence and mortality worldwide: Sources, methods and major patterns in GLOBOCAN 2012'. International journal of cancer. 2015;136(5):E359-86.

19. Fung MFK, Bryson P, Johnston M, Chambers A. (2004) 'Screening postmenopausal women for ovarian cancer: A systematic review', Journal of obstetrics and gynaecology Canada: JOGC = Journal d'obstetrique et gynecologie du Canada : JOGC, vol. 26, no. 8, pp. 717-728.

20. Gao Y-C, Wu J. 'MicroRNA-200c and microRNA-141 as potential diagnostic and prognostic biomarkers for ovarian cancer'. Tumour biology: the journal of the International Society for Oncodevelopmental Biology Medicine. 2015;36(6):4843-50.

21. Gasparri ML, Casorelli A, Bardhi E, Besharat AR, Savone D, Ruscito I, Farooqi AA, Papadia A, Mueller MD, Ferretti E, Panici B, P. 'Beyond circulating microRNA biomarkers: Urinary microRNAs in ovarian 
and breast cancer'. Tumour biology: the journal of the International Society for Oncodevelopmental Biology Medicine. 2017;39(5):1010428317695525.

22. Giannakakis A, Sandaltzopoulos R, Greshock J, Liang S, Huang J, Hasegawa K, Li C, O'Brien-Jenkins A, Katsaros D, Weber BL, Simon C, Coukos G, Zhang L. 'miR-210 links hypoxia with cell cycle regulation and is deleted in human epithelial ovarian cancer'. Cancer Biol Ther. 2008;7(2):255-64.

23. Grivennikov SI, Greten FR, Karin M. (2010) 'Immunity, inflammation, and cancer', Cell, vol. 140, no. 6, pp. 883-899.

24. Harris AL. 'Hypoxia-a key regulatory factor in tumour growth'. Nat Rev Cancer. 2002;2(1):38-47.

25. Häusler SFM, Keller A, Chandran PA, Ziegler K, Zipp K, Heuer S, Krockenberger M, Engel JB, Hönig A, Scheffler M, Dietl J, Wischhusen J. 'Whole blood-derived miRNA profiles as potential new tools for ovarian cancer screening'. British journal of cancer. 2010;103(5):693-700.

26. Heneghan HM, Miller N, Lowery AJ, Sweeney KJ, Newell J, Kerin MJ. 'Circulating microRNAs as novel minimally invasive biomarkers for breast cancer'. Annals of surgery. 2010;251(3):499-505.

27. Hong F, Li Y, Xu Y, Zhu L. 'Prognostic significance of serum microRNA-221 expression in human epithelial ovarian cancer'. J Int Med Res. 2013;41(1):64-71.

28. Howlader N, Noon AM, Krapcho M, et al. (2017) SEER Cancer Statistics Review 1975-2014 [Online].

29. Howlader N, Noone AM, Krapcho M, Miller D, Bishop K, Kosary CL, Yu M, Ruhl J, Tatalovich Z, Mariotto A, Lewis DR, Chen HS, Feuer EJ, Cronin KA, editors. (based on 2016 SEER data submission, posted to the SEER web site, 2017.) SEER Cancer Statistics Review, 1975-2014, National Cancer Institute. Bethesda, MD, [Online]. Available at https://seer.cancer.gov/csr/1975_2014/.

30. Iorio MV, Visone R, Di Leva G, Donati V, Petrocca F, Casalini P, Taccioli C, Volinia S, Liu C-G, Alder H, Calin GA, Ménard S, Croce CM. 'MicroRNA signatures in human ovarian cancer'. Cancer research. 2007;67(18):8699-707.

31. Jacobs IJ, Menon U, Ryan A, Gentry-Maharaj A, Burnell M, Kalsi JK, Amso NN, Apostolidou S, Benjamin E, Cruickshank D, Crump DN, Davies SK, Dawnay A, Dobbs S, Fletcher G, Ford J, Godfrey K, Gunu R, Habib M, Hallett R, Herod J, Jenkins H, Karpinskyj C, Leeson S, Lewis SJ, Liston WR, Lopes A, Mould T, Murdoch J, Oram D, Rabideau DJ, Reynolds K, Scott I, Seif MW, Sharma A, Singh N, Taylor J, Warburton F, Widschwendter M, Williamson K, Woolas R, Fallowfield L, McGuire AJ, Campbell S, Parmar M, Skates SJ. (2016) 'Ovarian cancer screening and mortality in the UK Collaborative Trial of Ovarian Cancer Screening (UKCTOCS): A randomised controlled trial', The Lancet, vol. 387, no. 10022, pp. 945-956.

32. Jelovac D, Armstrong DK. 'Recent progress in the diagnosis and treatment of ovarian cancer'. Cancer J Clin. 2011;61(3):183-203.

33. Johnson SM, Grosshans H, Shingara J, Byrom M, Jarvis R, Cheng A, Labourier E, Reinert KL, Brown D, Slack FJ. (2005) 'RAS is regulated by the let-7 microRNA family', Cell, vol. 120, no. 5, pp. 635-647.

34. Kan CWS, Hahn MA, Gard GB, Maidens J, Huh JY, Marsh DJ, Howell VM. 'Elevated levels of circulating microRNA-200 family members correlate with serous epithelial ovarian cancer'. BMC Cancer. 2012;12:627. 
35. Kapetanakis N-I, Uzan C, Jimenez-Pailhes A-S, Gouy S, Bentivegna E, Morice P, Caron O, GourzonesDmitriev C, Le Teuff G, Busson P. (2015) 'Plasma miR-200b in ovarian carcinoma patients: Distinct pattern of pre/post-treatment variation compared to CA-125 and potential for prediction of progression-free survival', Oncotarget, vol. 6, no. 34, pp. 36815-36824.

36. Keller S, Sanderson MP, Stoeck A, Altevogt P. (2006) 'Exosomes: From biogenesis and secretion to biological function', Immunology letters, vol. 107, no. 2, pp. 102-108.

37. Kitamura T, Qian B-Z, Pollard JW. 'Immune cell promotion of metastasis'. Nat Rev Immunol. 2015;15(2):73-86.

38. Kobayashi H, Yamada Y, Sado T, Sakata M, Yoshida S, Kawaguchi R, Kanayama S, Shigetomi H, Haruta S, Tsuji Y, Ueda S, Kitanaka T. 'A randomized study of screening for ovarian cancer: A multicenter study in Japan'. International journal of gynecological cancer: official journal of the International Gynecological Cancer Society. 2008;18(3):414-20.

39. Kroh EM, Parkin RK, Mitchell PS, Tewari M. (2010) 'Analysis of circulating microRNA biomarkers in plasma and serum using quantitative reverse transcription-PCR (qRT-PCR)', Methods (San Diego, Calif.), vol. 50, no. 4, pp. 298-301.

40. Kulshreshtha R, Ferracin M, Wojcik SE, Garzon R, Alder H, Agosto-Perez FJ, Davuluri R, Liu C-G, Croce CM, Negrini M, Calin GA, Ivan M. (2007) 'A microRNA signature of hypoxia', Molecular and cellular biology, vol. 27, no. 5, pp. 1859-1867.

41. Liang H, Jiang Z, Xie G, Lu Y. 'Serum microRNA-145 as a novel biomarker in human ovarian cancer'. Tumour biology: the journal of the International Society for Oncodevelopmental Biology Medicine. 2015;36(7):5305-13.

42. Mai PL, Wentzensen N, Greene MH. (2011) 'Challenges related to developing serum-based biomarkers for early ovarian cancer detection', Cancer prevention research (Philadelphia, Pa.), vol. 4, no. 3, pp. 303-306.

43. Meng X, Joosse SA, Müller V, Trillsch F, Milde-Langosch K, Mahner S, Geffken M, Pantel K, Schwarzenbach H. 'Diagnostic and prognostic potential of serum miR-7, miR-16, miR-25, miR-93, miR-182, miR-376a and miR-429 in ovarian cancer patients'. British journal of cancer. 2015;113(9):1358-66.

44. Menon U, Gentry-Maharaj A, Hallett R, Ryan A, Burnell M, Sharma A, Lewis S, Davies S, Philpott S, Lopes A, Godfrey K, Oram D, Herod J, Williamson K, Seif MW, Scott I, Mould T, Woolas R, Murdoch J, Dobbs S, Amso NN, Leeson S, Cruickshank D, McGuire A, Campbell S, Fallowfield L, Singh N, Dawnay A, Skates SJ, Parmar M, Jacobs I. 'Sensitivity and specificity of multimodal and ultrasound screening for ovarian cancer, and stage distribution of detected cancers: Results of the prevalence screen of the UK Collaborative Trial of Ovarian Cancer Screening (UKCTOCS)'. Lancet Oncol. 2009;10(4):327-40.

45. Menon U, Griffin M, Gentry-Maharaj A. (2014) 'Ovarian cancer screening-current status, future directions', Gynecologic oncology, vol. 132, no. 2, pp. 490-495.

46. Miles GD, Seiler M, Rodriguez L, Rajagopal G, Bhanot G. (2012) 'Identifying microRNA/mRNA dysregulations in ovarian cancer', BMC research notes, vol. 5, p. 164. 
47. Moldovan L, Batte KE, Trgovcich J, Wisler J, Marsh CB, Piper M. 'Methodological challenges in utilizing miRNAs as circulating biomarkers'. J Cell Mol Med. 2014;18(3):371-90.

48. Morgan RJ, Armstrong DK, Alvarez RD, Bakkum-Gamez JN, Behbakht K, Chen L-M, Copeland L, Crispens MA, DeRosa M, Dorigo O, Gershenson DM, Gray HJ, Hakam A, Havrilesky LJ, Johnston C, Lele S, Martin L, Matulonis UA, O'Malley DM, Penson RT, Percac-Lima S, Pineda M, Plaxe SC, Powell MA, Ratner E, Remmenga SW, Rose PG, Sabbatini P, Santoso JT, Werner TL, Burns J, Hughes M. 'Ovarian Cancer, Version 4.2017, NCCN Clinical Practice Guidelines in Oncology'. Journal of the National Comprehensive Cancer Network: JNCCN. 2017;14(9):1134-63.

49. Moss EL, Hollingworth J, Reynolds TM. 'The role of CA125 in clinical practice'. J Clin Pathol. 2005;58(3):308-12.

50. Nakamura K, Sawada K, Yoshimura A, Kinose Y, Nakatsuka E, Kimura T. (2016) 'Clinical relevance of circulating cell-free microRNAs in ovarian cancer', Molecular cancer, vol. 15, no. 1, p. 48.

51. Nam EJ, Yoon H, Kim SW, Kim H, Kim YT, Kim JH, Kim JW, Kim S. 'MicroRNA expression profiles in serous ovarian carcinoma'. Clinical cancer research: an official journal of the American Association for Cancer Research. 2008;14(9):2690-5.

52. Navickas R, Gal D, Laucevičius A, Taparauskaitė A, Zdanytė M, Holvoet P. 'Identifying circulating microRNAs as biomarkers of cardiovascular disease: A systematic review'. Cardiovascular research. 2016;111(4):322-37.

53. Paladini L, Fabris L, Bottai G, Raschioni C, Calin GA, Santarpia L. 'Targeting microRNAs as key modulators of tumor immune response'. Journal of experimental clinical cancer research: CR. 2016;35:103.

54. Pecot CV, Rupaimoole R, Yang D, Akbani R, Ivan C, Lu C, Wu S, Han H-D, Shah MY, Rodriguez-Aguayo C, Bottsford-Miller J, Liu Y, Kim SB, Unruh A, Gonzalez-Villasana V, Huang L, Zand B, Moreno-Smith M, Mangala LS, Taylor M, Dalton HJ, Sehgal V, Wen Y, Kang Y, Baggerly KA, Lee J-S, Ram PT, Ravoori MK, Kundra V, Zhang X, Ali-Fehmi R, Gonzalez-Angulo A-M, Massion PP, Calin GA, Lopez-Berestein G, Zhang W, Sood, A. K. (2013) 'Tumour angiogenesis regulation by the miR-200 family', Nature communications, vol. 4, p. 2427.

55. Resnick KE, Alder H, Hagan JP, Richardson DL, Croce CM, Cohn DE. (2009) 'The detection of differentially expressed microRNAs from the serum of ovarian cancer patients using a novel real-time PCR platform', Gynecologic oncology, vol. 112, no. 1, pp. 55-59.

56. Rustin G, van der Burg M, Griffin C, Qian W, Swart AM. 'Early versus delayed treatment of relapsed ovarian cancer'. Lancet. 2011;377(9763):380-1.

57. Rustin GJS, van der Burg MEL, Griffin CL, Guthrie D, Lamont A, Jayson GC, Kristensen G, Mediola C, Coens C, Qian W, Parmar MKB, Swart AM. 'Early versus delayed treatment of relapsed ovarian cancer (MRC OV05/EORTC 55955): A randomised trial'. Lancet. 2010;376(9747):1155-63.

58. Shahab SW, Matyunina LV, Mezencev R, Walker LD, Bowen NJ, Benigno BB, McDonald JF. 'Evidence for the complexity of microRNA-mediated regulation in ovarian cancer: A systems approach'. PloS one. 2011;6(7):e22508. 
59. Shapira I, Oswald M, Lovecchio J, Khalili H, Menzin A, Whyte J, Dos Santos L, Liang S, Bhuiya T, Keogh M, Mason C, Sultan K, Budman D, Gregersen PK, Lee AT. 'Circulating biomarkers for detection of ovarian cancer and predicting cancer outcomes'. British journal of cancer. 2014;110(4):976-83.

60. Siegel RL, Miller KD, Jemal A. (2017) 'Cancer Statistics, 2017', CA: a cancer journal for clinicians, vol. 67, no. 1, pp. 7-30.

61. Siegel RL, Miller KD, Jemal A. (2018) 'Cancer statistics, 2018', CA: a cancer journal for clinicians, vol. 68, no. 1, pp. 7-30.

62. Suryawanshi S, Vlad AM, Lin H-M, Mantia-Smaldone G, Laskey R, Lee M, Lin Y, Donnellan N, KleinPatel M, Lee T, Mansuria S, Elishaev E, Budiu R, Edwards RP, Huang X. 'Plasma microRNAs as novel biomarkers for endometriosis and endometriosis-associated ovarian cancer'. Clinical cancer research: an official journal of the American Association for Cancer Research. 2013;19(5):1213-24.

63. Taylor DD, Gercel-Taylor C. (2008) 'MicroRNA signatures of tumor-derived exosomes as diagnostic biomarkers of ovarian cancer', Gynecologic oncology, vol. 110, no. 1, pp. 13-21.

64. Tili E, Michaille J-J, Wernicke D, Alder H, Costinean S, Volinia S, Croce CM. 'Mutator activity induced by microRNA-155 (miR-155) links inflammation and cancer'. Proc Natl Acad Sci USA. 2011;108(12):4908-13.

65. Valadi H, Ekström K, Bossios A, Sjöstrand M, Lee JJ, Lötvall JO. 'Exosome-mediated transfer of mRNAs and microRNAs is a novel mechanism of genetic exchange between cells'. Nat Cell Biol. 2007;9(6):654-9.

66. Vecchione A, Belletti B, Lovat F, Volinia S, Chiappetta G, Giglio S, Sonego M, Cirombella R, Onesti EC, Pellegrini P, Califano D, Pignata S, Losito S, Canzonieri V, Sorio R, Alder H, Wernicke D, Stoppacciaro A, Baldassarre G, Croce CM. 'A microRNA signature defines chemoresistance in ovarian cancer through modulation of angiogenesis'. Proc Natl Acad Sci USA. 2013;110(24):9845-50.

67. Velu VK, Ramesh R, Srinivasan AR. 'Circulating MicroRNAs as Biomarkers in Health and Disease'. Journal of clinical diagnostic research: JCDR. 2012;6(10):1791-5.

68. Wang G, Tam L-S, Li EK-M, Kwan BC-H, Chow K-M, Luk CC-W, Li PK-T, Szeto C-C. 'Serum and urinary cell-free MiR-146a and MiR-155 in patients with systemic lupus erythematosus'. J Rhuematol. 2010;37(12):2516-22.

69. Wang Z-H, Xu C-J. 'Research Progress of MicroRNA in Early Detection of Ovarian Cancer'. Chin Med J. 2015;128(24):3363-70.

70. Weber JA, Baxter DH, Zhang S, Huang DY, Huang KH, Lee MJ, Galas DJ, Wang K. (2010) 'The microRNA spectrum in 12 body fluids', Clinical chemistry, vol. 56, no. 11, pp. 1733-1741.

71. Wittmann J, Jäck H-M. (2010) 'Serum microRNAs as powerful cancer biomarkers', Biochimica et biophysica acta, vol. 1806, no. 2, pp. 200-207.

72. Wyman SK, Parkin RK, Mitchell PS, Fritz BR, O'Briant K, Godwin AK, Urban N, Drescher CW, Knudsen BS, Tewari M. 'Repertoire of microRNAs in epithelial ovarian cancer as determined by next generation sequencing of small RNA cDNA libraries'. PloS one. 2009;4(4):e5311. 
73. Xie J, Liu M, Li Y, Nie Y, Mi Q, Zhao S. (2014) 'Ovarian tumor-associated microRNA-20a decreases natural killer cell cytotoxicity by downregulating MICA/B expression', Cellular \& molecular immunology, vol. 11, no. 5, pp. 495-502.

74. Xu S, Tao Z, Hai B, Liang H, Shi Y, Wang T, Song W, Chen Y, OuYang J, Chen J, Kong F, Dong Y, Jiang S-W, Li W, Wang P, Yuan Z, Wan X, Wang C, Li W, Zhang X, Chen K. 'miR-424(322) reverses chemoresistance via T-cell immune response activation by blocking the PD-L1 immune checkpoint'. Nature communications. 2016;7:11406.

75. Yamada Y, Enokida H, Kojima S, Kawakami K, Chiyomaru T, Tatarano S, Yoshino H, Kawahara K, Nishiyama K, Seki N, Nakagawa M. 'MiR-96 and miR-183 detection in urine serve as potential tumor markers of urothelial carcinoma: Correlation with stage and grade, and comparison with urinary cytology'. Cancer Sci. 2011;102(3):522-9.

76. Yang H, Kong W, He L, Zhao J-J, O'Donnell JD, Wang J, Wenham RM, Coppola D, Kruk PA, Nicosia SV, Cheng JQ. 'MicroRNA expression profiling in human ovarian cancer: MiR-214 induces cell survival and cisplatin resistance by targeting PTEN'. Cancer research. 2008;68(2):425-33.

77. Záveský L, Jandáková $E$, Turyna $R$, Langmeierová L, Weinberger V, Záveská Drábková L, Hůlková $M$, Hořínek A, Dušková D, Feyereisl J, Minář L, Kohoutová M. (2015) ‘Evaluation of Cell-Free Urine microRNAs Expression for the Use in Diagnosis of Ovarian and Endometrial Cancers. A Pilot Study', Pathology oncology research: POR, vol. 21, no. 4, pp. 1027-1035.

78. Zhang L, Volinia S, Bonome T, Calin GA, Greshock J, Yang N, Liu C-G, Giannakakis A, Alexiou P, Hasegawa K, Johnstone CN, Megraw MS, Adams S, Lassus H, Huang J, Kaur S, Liang S, Sethupathy P, Leminen A, Simossis VA, Sandaltzopoulos R, Naomoto Y, Katsaros D, Gimotty PA, DeMichele A, Huang Q, Bützow R, Rustgi AK, Weber BL, Birrer MJ, Hatzigeorgiou AG, Croce CM, Coukos G. (2008) 'Genomic and epigenetic alterations deregulate microRNA expression in human epithelial ovarian cancer', Proceedings of the National Academy of Sciences of the United States of America, vol. 105, no. 19 , pp. 7004-7009.

79. Zheng H, Zhang L, Zhao Y, Yang D, Song F, Wen Y, Hao Q, Hu Z, Zhang W, Chen K. 'Plasma miRNAs as diagnostic and prognostic biomarkers for ovarian cancer'. PloS one. 2013;8(11):e77853.

80. Zhou J, Gong G, Tan H, Dai F, Zhu X, Chen Y, Wang J, Liu Y, Chen P, Wu X, Wen J. 'Urinary microRNA30a-5p is a potential biomarker for ovarian serous adenocarcinoma'. Oncol Rep. 2015;33(6):291523.

81. Zuberi M, Mir R, Das J, Ahmad I, Javid J, Yadav P, Masroor M, Ahmad S, Ray PC, Saxena A. 'Expression of serum miR-200a, miR-200b, and miR-200c as candidate biomarkers in epithelial ovarian cancer and their association with clinicopathological features'. Clinical translational oncology: official publication of the Federation of Spanish Oncology Societies of the National Cancer Institute of Mexico. 2015;17(10):779-87.

82. Additional files.

83. Additional file 1 (Additional file 1.docx): Box plots. 
84. Shows box plots of relative expression levels. of all analyzed miRNAs in the cell lines EFO-27, OAW42 and SK-OV-3, in both compartments (intra (A)- and extracellular (B)) and under all analyzed treatments (untreated $(\mathrm{N})$, hypoxia $(\mathrm{Hx})$ and acidosis $(\mathrm{Ac})$ ) as well as box plots of all analyzed miRNAs in OC patients (OC) compared to healthy controls (CTRL).

\section{Additional file 2 (Additional file 2.csv): Raw data.}

86. Shows $\Delta C_{t}$-values of five cell culture sets $(1-5)$ intra- and extracellularly of the three cell lines EFO27, OAW-42 and SK-OV-3 under all analyzed treatments (untreated $(\mathrm{N})$, hypoxia $(\mathrm{Hx})$ and acidosis (Ac)).

\section{Additional file 3 (Additional file 1.txt): Results generated by $\mathbf{R}$.}

88. Shows relative expression. levels, confidence intervals and $p$-values of each cell line after the statistical analysis generated by $\mathrm{R}$.

89. Shows relative expression levels, confidence intervals and p-values of each cell line after the statistical analysis generated by $\mathrm{R}$.

\section{Figures}
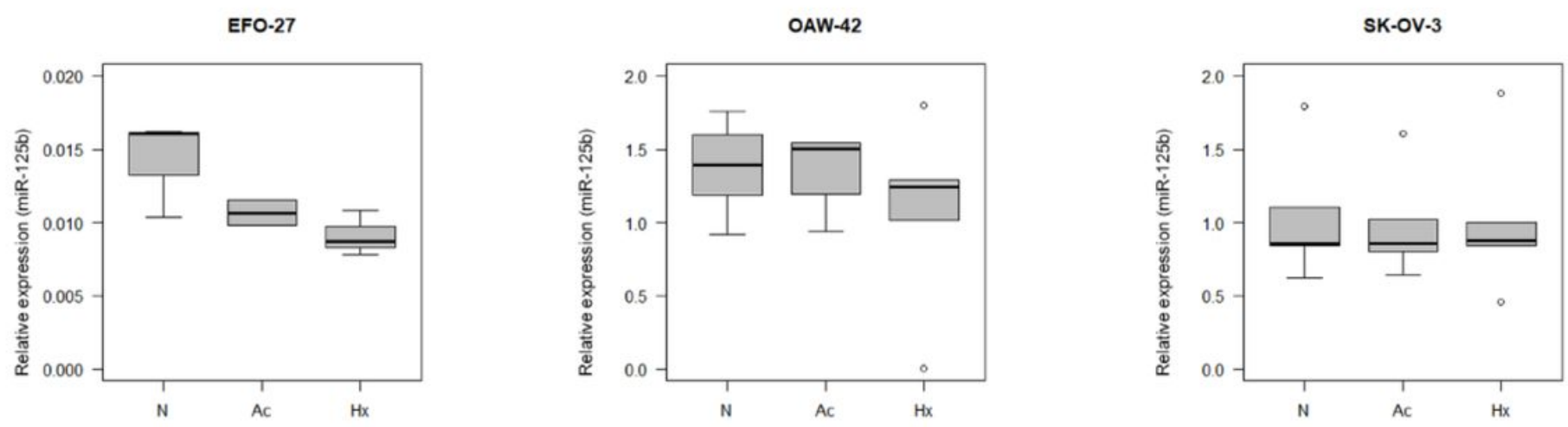

Figure 1: Intracellular relative expression of miR-125b in EFO-27, OAW-42 and SK-OV-3 cells. N: control, Ac: acidosis, Hx: hypoxia

\section{Figure 1}

Intracellular relative expression of miR-125b in EFO-27, OAW-42 and SK-OV-3 cells. N: control, Ac: acidosis, $\mathrm{Hx}$ : hypoxia 

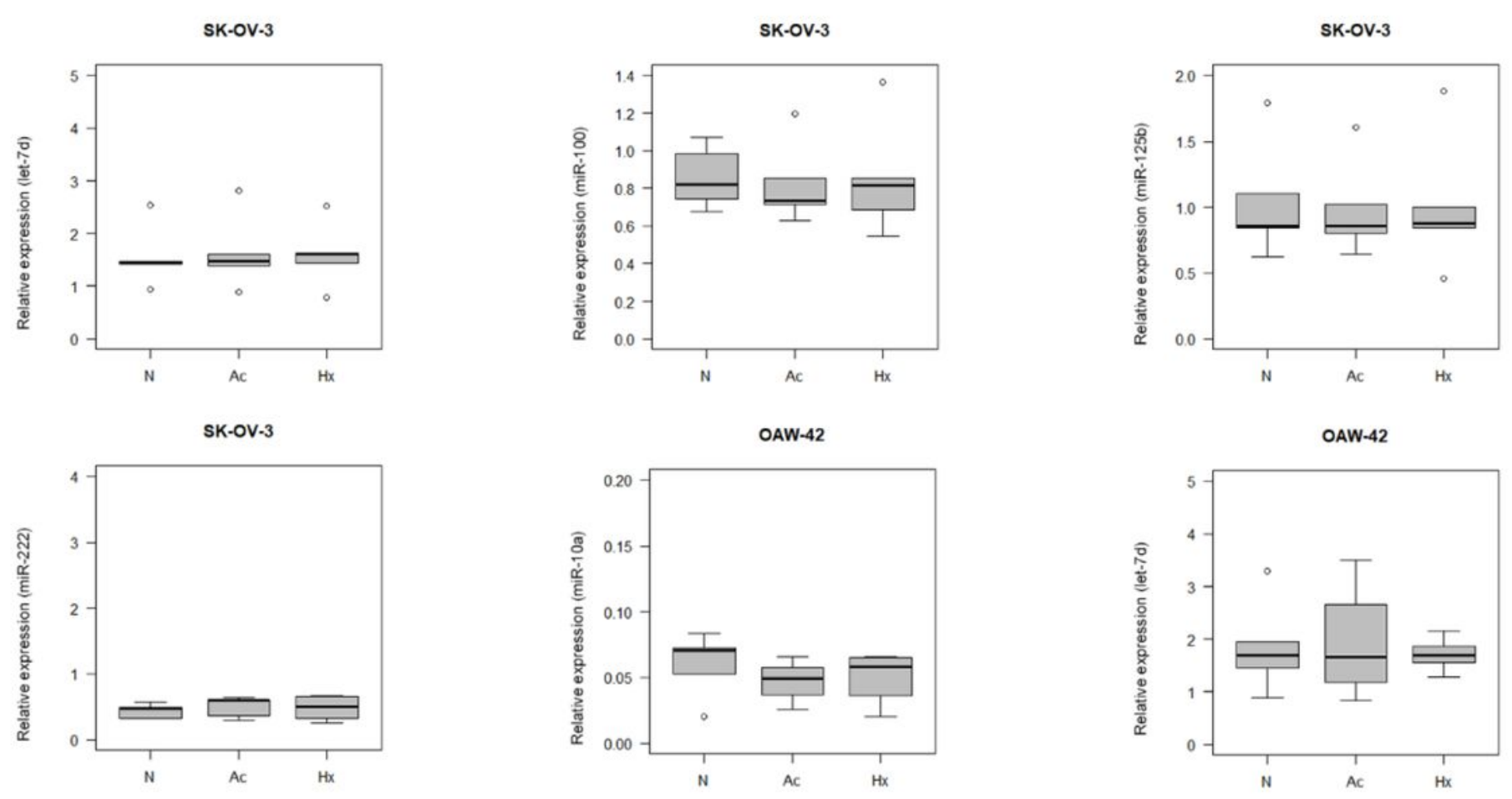

Figure 2: Intracellular relative expression of let-7d, miR-100, miR-125b and miR-222 in SK-OV-3 cells and of let-7d and miR-10a in OAW-42 cells. $\mathrm{N}$ : control, Ac: acidosis, $\mathrm{Hx}$ : hypoxia

\section{Figure 2}

Intracellular relative expression of let-7d, miR-100, miR-125b and miR-222 in SK-0V-3 cells and of let-7d and miR-10a in OAW-42 cells. N: control, Ac: acidosis, $\mathrm{Hx}$ : hypoxia 

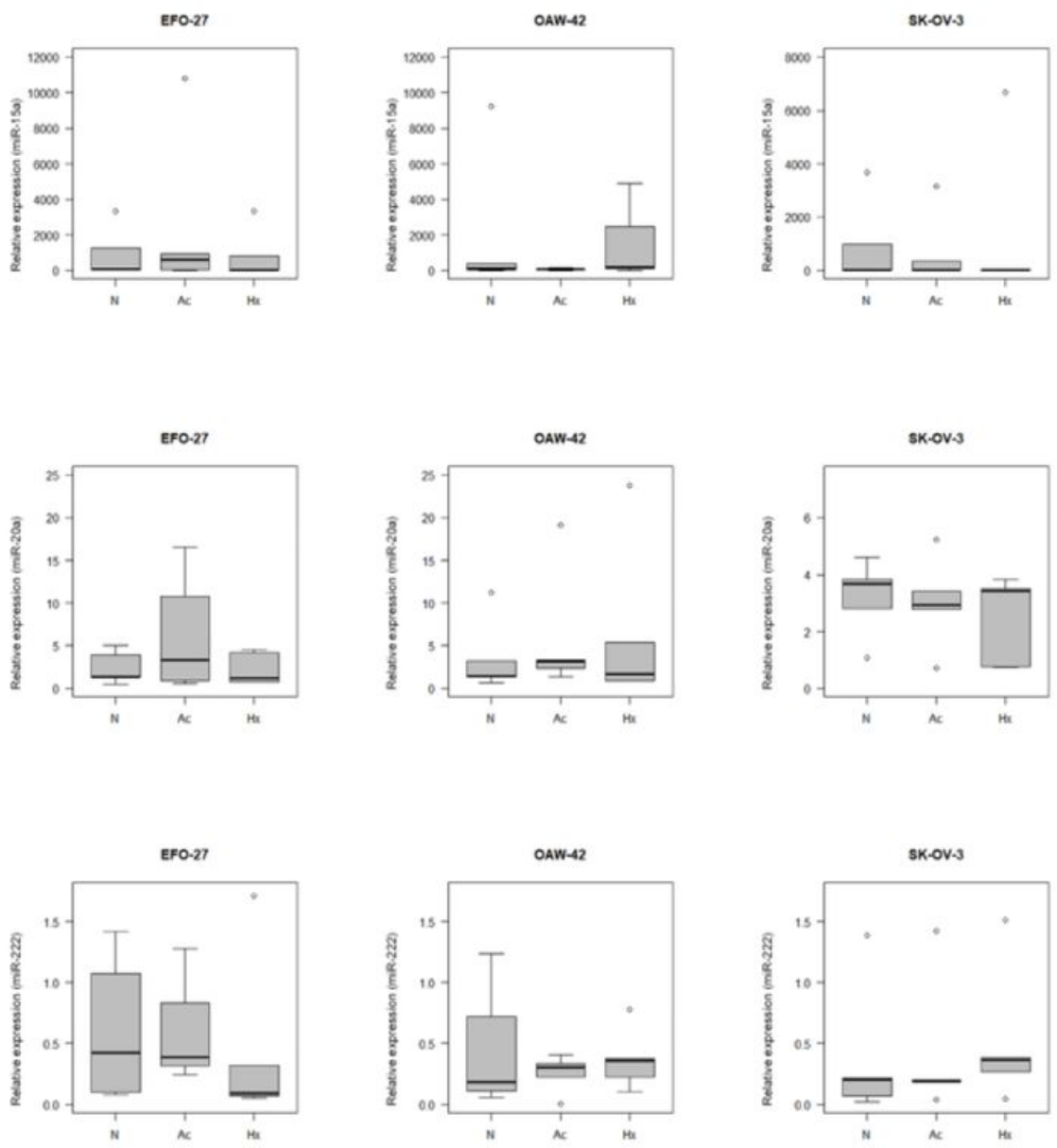

Figure 3: Extracellular expression alterations: miR-15a, miR-20a and miR-222 in EFO-24, OAW-42 and SKOV-3 cells. N: control, Ac: acidosis, $\mathrm{Hx}$ : hypoxia

\section{Figure 3}

Extracellular expression alterations: miR-15a, miR-20a and miR-222 in EFO-24, OAW-42 and SK-OV-3 cells. $\mathrm{N}$ : control, Ac: acidosis, Hx: hypoxia 

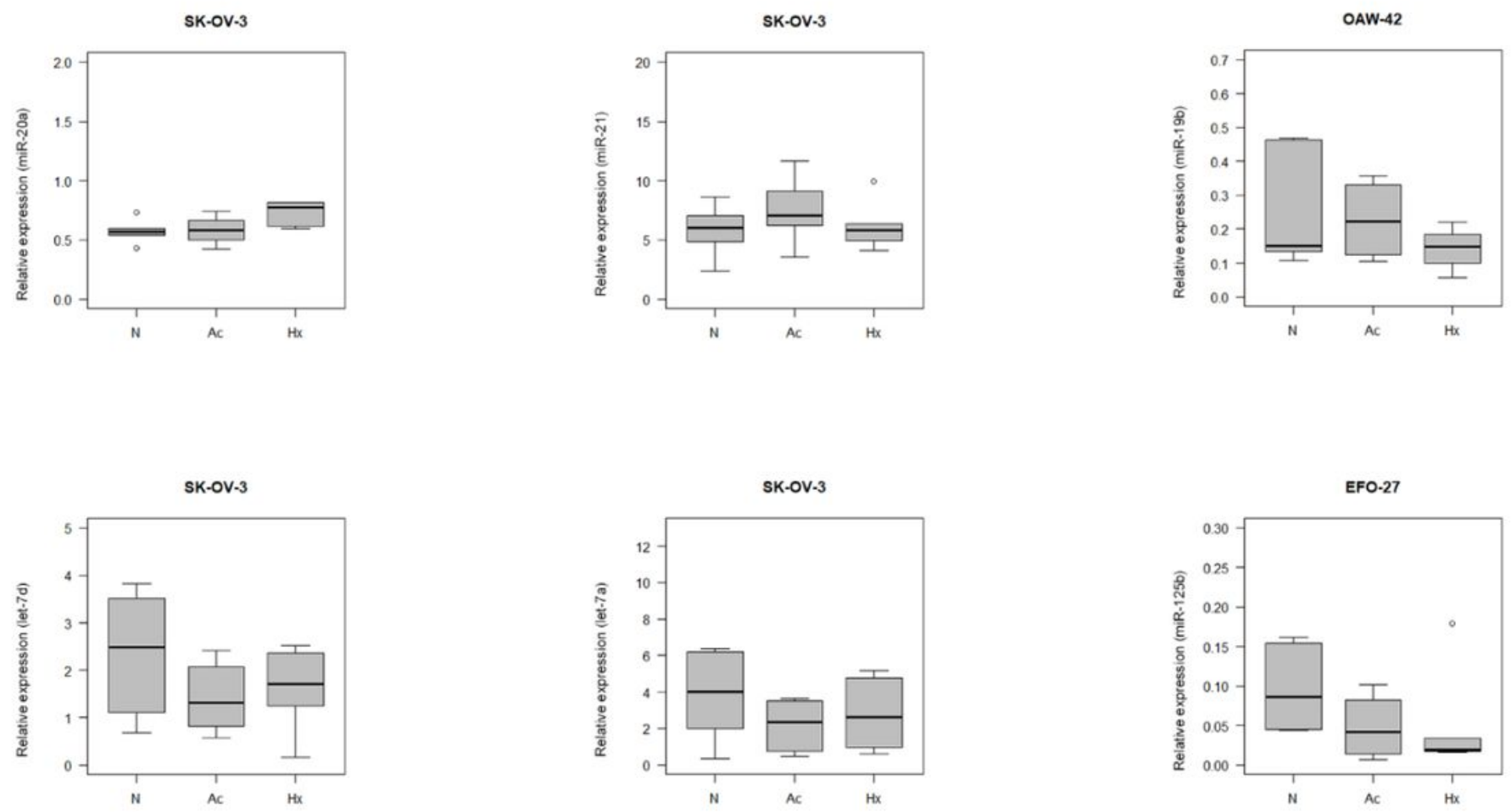

Figure 4: Regulated miRs under hypoxia and acidosis. Top row - intracellularly: upregulation of miR-20a under hypoxia and of miR-21 under acidosis in SKOV-3 cells; upregulation of miR-19b under acidosis in OAW-42 cells. Bottom row - extracellularly: downregulation of let-7d under hypoxia and let-7d and let7a under acidosis in SK-OV-3 cells; downregulation of miR-125b under acidosis in EFO-27 cell. N: control, Ac: acidosis, Hx: hypoxia

\section{Figure 4}

Regulated miRs under hypoxia and acidosis. N: control, Ac: acidosis, Hx: hypoxia
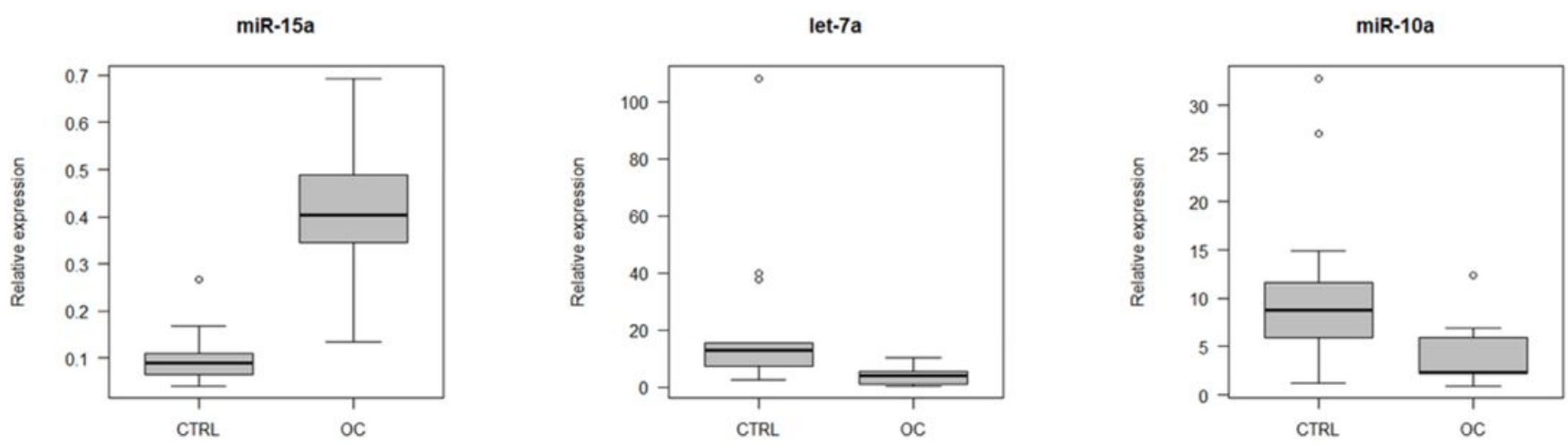

Figure 5: Deregulated miRNAs in the urine of OC patients compared to HC. Relative expressions shown. CTRL: healthy controls, OC: ovarian cancer patients 
Figure 5

Deregulated miRNAs in the urine of OC patients compared to HC. Relative expression is shown. CTRL: healthy controls, OC: ovarian cancer patients

\section{Supplementary Files}

This is a list of supplementary files associated with this preprint. Click to download.

- Additionalfile1.docx

- Additionalfile3.txt

- Additionalfile2.csv 